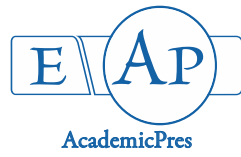

\title{
Anatomical and Phytochemical Studies on Benincasa bispida (Thunb.) Cogn. (Cucurbitaceae)
}

\author{
Chimezie EKEKE*, Chinedum A. OGAZIE, Ikechukwu O. AGBAGWA \\ University of Port Harcourt, Faculty of Science, Department of Plant Science and Biotechnology, Nigeria; ekeke.uche@uniport.edu.ng; \\ ogazie.chinedum@uniport.edu.ng; ikechukwu.agbagwa@uniport.edu.ng (*correspondingauthor); ekeke.uche@uniport.edu.ng
}

\begin{abstract}
The morphological and anatomical studies of Benincasa hispida (Thunb.) Cogn. from Nigeria was carried out with the view to reporting morphological and anatomical characteristics for the first time. Physical and microscopic (microtomy) observations were used. B. hispida is a monoecious climbing or trailing herb, stem hairy, 5-angled, with suborbicular stipuliform bract at the petiole-base; leaves simple, very hairy on both surface, alternate, blade palmately or ovate in young plant, base cordate. Flowering occurs between April and May. Female flowers solitary, male flowers solitary or in a slenderpedunculate racemes, petals-5, cream, yellow or pale yellow, ovary ellipsoid, ovules many, stigma 3-lobed and stamen 3 . Fruits are large, weighs $8.5-9.0 \mathrm{~kg}$, succulent, densely hairy when young, with a thick waxy deposit when mature, cylindrical to oblong with hairy stalk. Seeds are ovate-obovate, cream. Leaves and petals of male flower are amphistomatic with anomocytic, tetracytic and anisocytic stomata while petals of the female flower are hypostomatic with anomocytic stomata only on the abaxial surface. It has glandular and non-glandular trichomes with uniseriate stalk, clavate and multicellular gland heads. The midrib, petiole, stem, tendril, male and female flower stalks and tendril have hollow pith with 3, 9, 6-7, 16, 14 and 10 bicollateral vascular bundles respectively. The percentage crude protein, ash, carbohydrate, lipid, crude fibre, alkaloid, flavonoid, tannin and phytate could account for the numerous medicinal properties.
\end{abstract}

Keywords: amphistomatic; anatomy; Benincasa bispida; glandular trichome; hypostomatic; morphology; phytochemical

\section{Introduction}

The Cucurbitaceae is most diverse in tropical and subtropical regions with hotspots in Southeast Asia, West Africa, Madagascar, and Mexico (Schaefer and Renner, 2011) and is divided into two subfamilies Nhandiroboideae also called Zanonioideae (Jeffrey, 1990) with 19 genera and 60 species and Cucurbitoideae with 111 genera and 740 species. The subfamily Cucurbitoideae comprises some of the most important tribes and genera within cucurbits. These include Benincaseae (Benincasa, Citrullus, Coccinia, Lagenaria, Cucumeropsis, Cucumis and Zehneria), Luffeae (Luffa), Cucurbiteae (Cucurbita), Sicyeae (Cyclanthera, Sechium), Joliffieae (Momordica, Telfairia), Schizopeponeae (Schizopepon), Trichosantheae (Hodgsonia, Trichosanthes), Bryonieae (Ecballium), Herpetospermae and Coniandreae (Jeffrey, 1990; Rubatzky and Yamaguchi, 1997; Jeffrey, 2005).

Benincasa (Cucurbitaceae) is a monotypic genus with a single species. It is indigenous to both arid and temperate regions of the earth and requires long periods of warm, dry weather for their optimal growth (Whitaker and Davis,
1962). It is under cultivation in large areas in Indian states (Cheran et al., 2010). B. hispida has a chromosome number of $2 \mathrm{n}=24$ (Mini-Raj et al., 1993; Robinson and DeckerWalters, 1993) and four cultivars based on the size, shape, fuzziness, waxiness, and presence or absence of a dusty or ashy layer (Rubatsky and Yamaguchi, 1997). The fruits of this species could be medium or large and weigh from 7.5 to $45 \mathrm{~kg}$ depending on genotype and the production system (Rubatzky and Yamaguchi, 1997; Stephens, 1988) with varying shapes (oblong to cylindrical or elongated) (Stephens, 1988; Rubatzky and Yamaguchi, 1997).

B. hispida is widely used as medicine and has nutritional, pharmacological and medicinal properties some of which include antioxidant activity (Mingyu et al., 1995; Yoshizumi et al., 1998; Huang et al., 2004; Du et al., 2005), anti-compulsive effect (Girdhar et al., 2010), angiotensionconverting enzyme (ACE) inhibitor activity in vitro (Huang et al., 2004; Bhalodia et al., 2009), Alzheimer disease treatment (Cantuti et al., 2000; Maciuk et al., 2002; Roy et al., 2008), anti-ulcer (Grover et al., 2001; Shetty et al., 2008; Rachchh and Jain, 2009), anti-inflammatory (Cuzzocrea et al., 2001; Chandrababu and Umamaheshwari, 2002; Shetty 
et al., 2008; Gill et al., 2010), anti-obesity (Zhang, 1996; Kumar and Vimalavathini, 2004; Nadhiya et al., 2016) and anti-diarrheal agent (Ammon et al., 1974; Gaginella et al., 1975; Mathad et al., 2005). The fruits contain volatile oils, flavonoids, glycosides, sacchrides, proteins, carotenes, vitamins, minerals, ß-sitosterin and uronic acid (Nurul et al., 2011).

Among Nigerian cucurbits, there are many works on their anatomy and morphology (Okoli 1984; Ndukwu and Okoli, 1992; Agbagwa and Ndukwu, 2004; Aguoru and Okoli, 2012; Ajuru and Okoli, 2013; Agogbua et al., 2015a; Ekeke et al., 2015), cytology (Okoli, 1984, 1987; Agbagwa, et al., 2007), ethno-botanical values (Chike et al., 2006; Omara-Achong et al., 2012) and polyploidy induction (Agogbua et al., 2015b; Agogbua and Ekeke, 2017). However, there is no record on the occurrence of B. hispida in Nigerian. It is yet to be described and is scarcely studied. There is relatively no report on the morphology, anatomy, phytochemistry and cytology of this species from Nigeria. This work presents the first report on the morphology, anatomy and phytochemistry $B$. hispida from Nigeria.

\section{Materials and Methods}

\section{Source of plantmaterial}

The plant material studied in this work was collected from the University of Port Harcourt Biodiversity Center (a forest over 50 year old), South-South, Nigeria. The plant was identified, processed and deposited in the University of Port Harcourt Herbarium (UPH/V/1264). The morphological attributes of the species were described and recorded.

\section{Epidermalstudies}

Foliar materials for epidermal studies were collected fresh from plants growing in the wild. The adaxial and abaxial epidermal surfaces were peeled, stained with $1 \%$ safranin or alcian blue, rinsed with distilled water to remove excess stain, mounted in a drop of pure glycerine on clean glass slides; coverslips placed over the peels and sealed with nail varnish to prevent dehydration (Ndukwu and Okoli, 1992). The slides were observed using a microscope and the epidermal features described by Metcalfe and Chalk (1979) and stomatal types described according to Malvey (2004).

\section{Anatomical studies}

Cut sections of petiole, midrib from matured leaves and young stems were fixed in FAA (formaldehyde:glacial acetic acid:ethanol in the ratio of 1:1:18 parts of $70 \%$ ethanol $\mathrm{v} / \mathrm{v}$ ) for at least 48 hours. These materials were washed in several changes of distilled water, dehydrated through alcohol series (30\%, 50\%, 70\% and 100\%) solution 2 hours in each and embedded in wax. Sections were cut on a Leitz 1512 rotary microtome at thickness between $15-20 \mu \mathrm{m}$. The thin sections selected were de-waxed and stained with $1 \%$ Safranin O and counterstained with Alcian blue, mounted on slides and photomicrographs of the anatomical sections taken with Leitz Diaplan photomicroscope fitted with Leica WILD MPS 52 camera.

\section{Proximate and phytochemical studies}

The leaves of these plant species were detached washed with distilled water, air-dried, ground into powder using and electronic blender, sieved with 80 micron mesh and $200 \mathrm{~g}$ of each sample stored in glass bottles. The samples were analysed for crude protein, ash and crude fibre according to the AOAC Official Method (AOAC, 2000), $920.152,930.05,948.22$ and 935.53 respectively. The method of determination of phytochemicals were oxalates (Sanchez-Alonso and Lachica, 1987), alkaloids and flavonoid (Harborne, 1973), saponins (Obadoni and Ochuko, 2001), lipid (Yaniv et al., 1999) and tannin (AOAC, 2006).

\section{Results}

\section{Habit, habitat and morphology of B. hispida}

B. hispida grows on moist soils, sandy or seasonal flood plain. It is a monoecious climbing or trailing herb; stem hairy, 5-angled, with suborbicular stipuliform bract at the petiole-base; internode $10.2-13.1 \mathrm{~cm}$; leaves simple, 9.8 $14.1 \mathrm{~cm}$ long, $1.0-1.7 \mathrm{~cm}$ wide, very hairy on both surface, alternate, blade palmately 5-7-lobed or ovate in young plant, lobes ovate-triangular or triangular, apex acute acuminate, base cordate; petiole hairy, $5.8-11.0 \mathrm{~cm}$ long; 6 - 7-angled; tendril bifid at $1.8-2.7 \mathrm{~cm}$ (Figs. 1a, 1b, 1c and 1d). Flowering occurs between April and May. Female flowers solitary, petals-5, cream, yellow or pale yellow, $4.0 \mathrm{x}$ $5.0 \mathrm{~cm}$; ovary ellipsoid, ovules many, receptacle-tube short, stigma 3-lobed, pedicle very hairy, $1.0-1.5 \mathrm{~cm}$ long (Fig. 1e). Male flowers solitary or in a slender-pedunculate racemes; fairly coaxillary with female flowers, petals-5, yellow or cream, entire, hairy, campanulate, receptacle-tube relatively short and broad, tube $0.6-1.0 \mathrm{~cm}$; sepals hairy, ovateobovate, $3.8 \times 4.6 \mathrm{~cm}$, apex acute, pedicles slender, $4.8-8.1$ $\mathrm{cm}$ long; stamen 3, filaments free, inserted on the tube (Fig. 1f).

Fruits are large, succulent, densely hairy when young (Figs. 2a and 2b), with a thick waxy deposit when mature and $58.6-59.4 \times 14.0-15.5 \mathrm{~cm}$ (Figs. $2 \mathrm{c}$ and $2 \mathrm{~d}$ ), cylindrical to oblong with hairy stalk (Fig. 2e). Matured fruits weigh 8.5 - $9.0 \mathrm{~kg}$. Seeds are ovate-obovate, cream, $7.8-12.9 \mathrm{~mm}$ long, $5.7-7.0 \mathrm{~mm}$ wide, $1.5-2.4 \mathrm{~mm}$ thick, 100 seeds weigh $4.12-5.10 \mathrm{~g}$ (Fig. 2h).

\section{Epidermal characteristics}

Three stomata types namely anomocytic, tetracytic and anisocytic occurred in this species (Fig. 3 and Table 1).

\section{Leaves}

The leaf is amphistomatic. The abaxial (upper) and adaxial (lower) epidermises have anomocytic, tetracytic and anisocytic stomata with the anomocytic and tetracytic stomata predominating. The shape of the adaxial epidermal cells are irregular (Fig. 3A) while the abaxial epidermal cells are polygonal (Fig. 3B). The adaxial anticlinal cell walls are slightly straight or curved while the abaxial ones are undulating. The stomatal indexes are $80.86 \pm 2.59$ and $32.39 \pm 5.11$ on the lower and upper epidermises respectively (Table 1). 
104

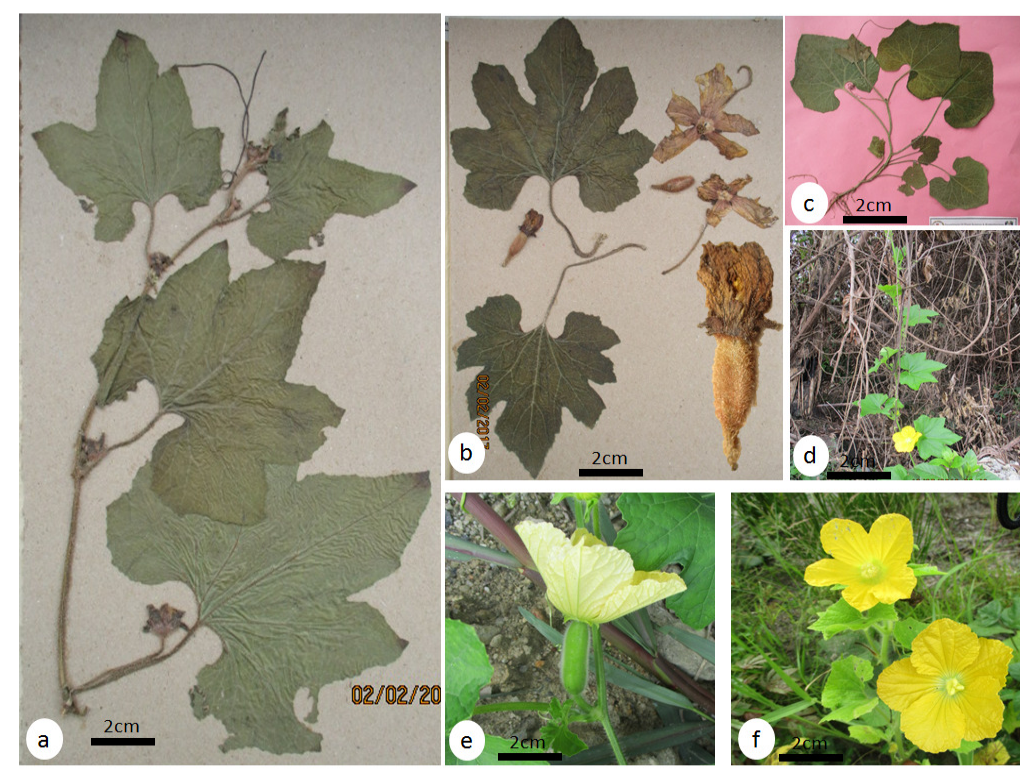

Fig. 1. Vegetative and reproductive parts of B. hispida: a - c. voucher specimens-UPH/V/1264, a \& b. mature plants, c. seedling, d. plant habit, e. female flower and f. male flower

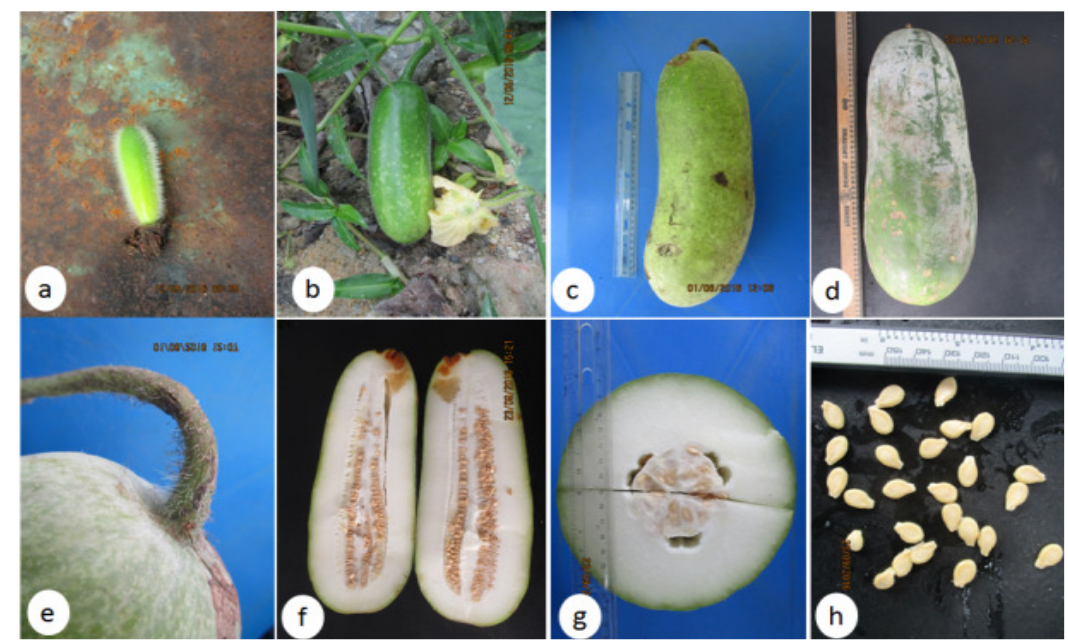

Fig. 2. Fruits and seeds of B. hispida: a - c. young/immature fruits, d. mature fruit, e. hairy fruit-stalk, f. longitudinal view of the fruit, g. transvers view of the fruit, and h. seeds

Table 1. Epidermal characteristics of leaf, male and female flowers of B. hispida

\begin{tabular}{|c|c|c|c|c|c|c|}
\hline \multirow{2}{*}{$\begin{array}{l}\text { Epidermal } \\
\text { character }\end{array}$} & \multicolumn{2}{|c|}{ Leaf } & \multicolumn{2}{|c|}{ Male flower } & \multicolumn{2}{|c|}{ Female flower } \\
\hline & Adaxial & Abaxial & Adaxial & Abaxial & Adaxial & Abaxial \\
\hline $\begin{array}{c}\text { Shape of } \\
\text { epidermal cell }\end{array}$ & Polygonal & Irregular & Polygonal & Irregular & $\begin{array}{c}\text { Regular and partly } \\
\text { Irregular }\end{array}$ & Irregular \\
\hline $\begin{array}{l}\text { Anticlinal cell } \\
\text { wall pattern }\end{array}$ & $\begin{array}{c}\text { Slightly straight or } \\
\text { curved }\end{array}$ & Undulating & $\begin{array}{c}\text { Slightly straight or } \\
\text { curved }\end{array}$ & Undulating & Undulating & Undulating \\
\hline Stomata type & $\begin{array}{l}\text { Anomocytic, } \\
\text { tetracytic and } \\
\text { anisocytic }\end{array}$ & $\begin{array}{l}\text { Anomocytic, } \\
\text { tetracytic and } \\
\text { anisocytic }\end{array}$ & Anomocytic & $\begin{array}{c}\text { Anomocytic and } \\
\text { tetracytic }\end{array}$ & - & Amomocytic \\
\hline $\begin{array}{c}\text { Stomata index } \\
\text { (S.I) }\end{array}$ & $\begin{array}{c}29.03-40.0 \\
(32.39 \pm 5.11)\end{array}$ & $\begin{array}{l}77.78-83.87 \\
(80.86 \pm 2.59)\end{array}$ & $0.0-1.05(0.77 \pm 0.51)$ & $\begin{array}{l}7.14-7.69 \\
(7.45 \pm 0.24)\end{array}$ & $\begin{array}{l}4.76-10.53 \\
(7.99 \pm 2.95)\end{array}$ & 0.00 \\
\hline Trichome & + & + & + & + & & \\
\hline Glandular & + & + & - & + & + & \\
\hline
\end{tabular}




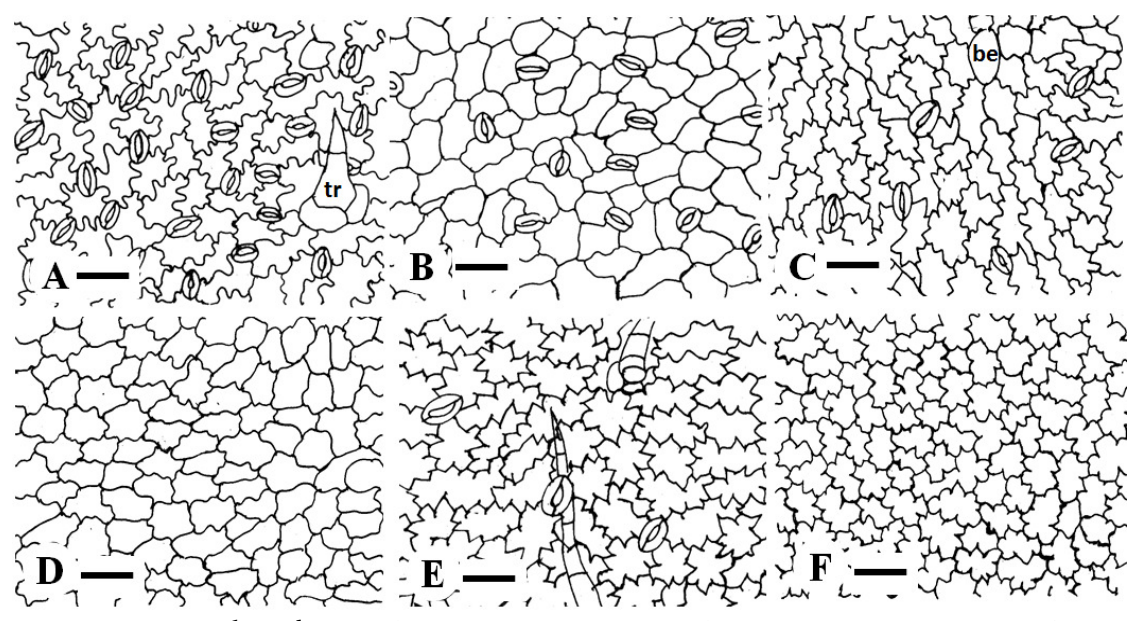

Fig. 3. Epidermal characteristic of B. hispida: Leaf (A and B); female flower (C and D) and male Flower (E and F) bar $=45 \mu \mathrm{m}$

\section{Male flower}

The petals of the male flower are amphistomatic having anomocytic and tetracytic stomata. Anomocytic and tetracytic stomata were recorded on the abaxial surface while adaxial surface had only anomcytic stomata (Figs. 3C and 3D). The adaxial anticlinal cell walls are slightly straight or curved while the abaxial ones are undulating. The stomatal indexes are $7.45 \pm 0.24$ and $0.77 \pm 0.51$ on the abaxial and adaxial surfaces respectively.

\section{Female flower}

The petals of the female flower are hypostomatic with anomocytic stomata only on the abaxial surface (Figs. 3E and $3 F$ ). The shape both abaxial and adaxial epidermal cells irregular and the anticlinal cell walls are undulating.

\section{Trichome types and distribution}

The trichomes present in this species are glandular and non-glandular with uniseriate stalk, clavate and multicellular gland heads (Fig. 4). The non-glandular trichome types (Figs. 4a, 4b, 4c and 4d) are found on the adaxial and abaxial surfaces of the male flower petals while glandular trichome types (Figs. 4g, 4h, 4i, 4j and $4 \mathrm{k}$ ) occurred on the adaxial epidermal surface of the male flower petals. The petals of the female flowers have glandular (multicellular gland head) trichome (Fig. 4i) and all the forms of non-glandular trichome identified on the lower epidermal surface of the male flower. Also the nonglandular trichome (Fig. 4l) and glandular trichome (Fig. 4i) were recorded on the adaxial surface of the leaf with the non-glandular types occurring mainly on the veins while the abaxial surface had trichome types (Figs. $4 \mathrm{f}$ and $4 \mathrm{~g}$ ).

\section{Anatomical characteristics}

The result of the anatomical characteristics of the midrib, petiole, stem, tendril, male and female flower stalks and tendril is presented in Table 2, Figs. 5, 6 and 7.

\section{Midrib/lamina}

The midrib has three bicollateral vascular bundles arranged parallel to each other (Figs. 5A, 5B). The lamina contains 1-layer of palisade mesophyll and loosely packed spongy mesophyll with intercellular spaces. The upper and lower epidermises comprised 1-layer of periclinally elongated cells (Fig. 5C).

\section{Petiole}

The petiole has hollow pith, $320-360 \mu \mathrm{m}$ wide, cortex $20-24 \mu \mathrm{m}$ thick, collenchyma $2-4 \mu \mathrm{m}$ thick with 9 vascular bundles (Table 2, Figs. 6A and B).

\section{Tendril}

The tendril has hollow pith, $180-220 \mu \mathrm{m}$ wide, cortex $64-76 \mu \mathrm{m}$ thick and sclerenchyma $2-3 \mu \mathrm{m}$ thick with $6-7$ vascular bundles ((Table 2, Figs. 6E and D).

\section{Male flower stalk}

The male flower stalk has hollow pith, $180-220 \mu \mathrm{m}$ wide, and cortex $53-64 \mu \mathrm{m}$ thick, and sclerenchyma $2-3$ $\mu \mathrm{m}$ thick and 16-vascular bundles (Table 2, Figs. $7 \mathrm{~A}$ and B).

\section{Female flower stalk}

The young female flower stalk pith is not hollow, cortex $112-116 \mu \mathrm{m}$ thick, sclerenchyma $2-3 \mu \mathrm{m}$ thick with 14 vascular bundles (Table 2, Figs. 7C and D).

Table 2. Anatomical Characteristics of B. hispida

\begin{tabular}{|c|c|c|c|c|c|}
\hline Plant part & Nature of pith & $\operatorname{TOC}(\mu \mathrm{m})$ & $\mathrm{DP}(\mu \mathrm{m})$ & NVB & $\mathrm{TS}(\mu \mathrm{m})$ \\
\hline Female flower stalk & Not hollow & $112-116$ & $340-400$ & 14 & $6-7$ \\
\hline Stem & Hollow & $83-96$ & $250-370$ & 10 & $3-4$ \\
\hline Midrib & Not hollow & NA & NA & 3 & NA \\
\hline Tendril & Hollow & $64-76$ & $180-220$ & $6-7$ & $2-3$ \\
\hline Petiole & Hollow & $20-24$ & $320-360$ & 9 & NA \\
\hline Male flower stalk & Hollow & $53-64$ & $500-540$ & 16 & $2-3$ \\
\hline
\end{tabular}


106
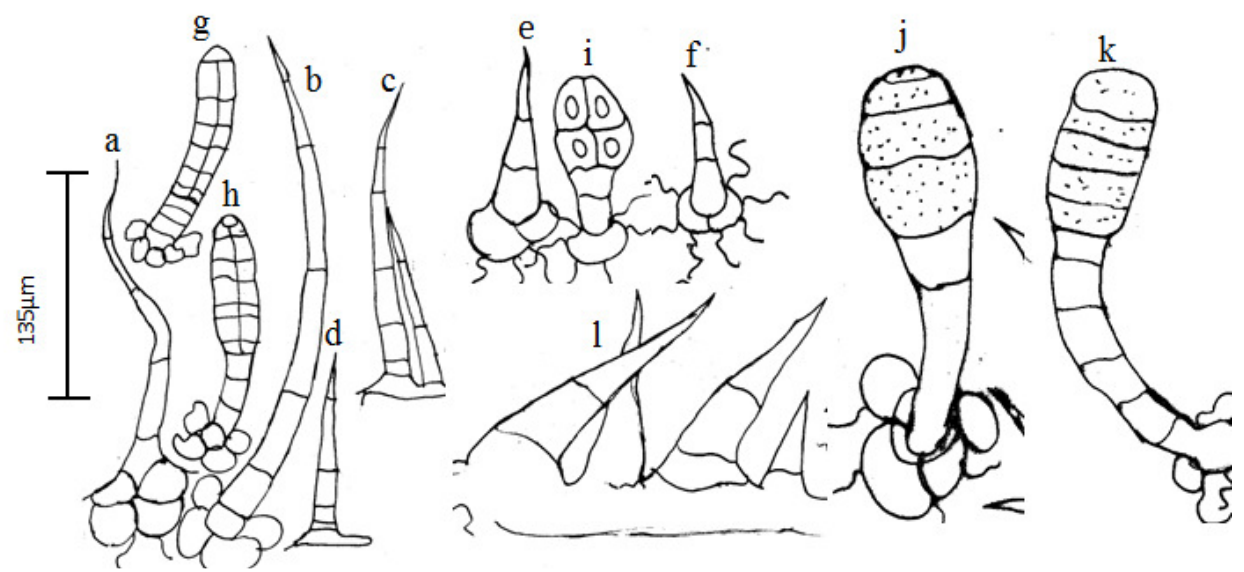

Fig. 4. Trichome types in B. hispida (a, b, c, d, e, f and l) non-glandular trichomes and (g, h, I, j and k) glandular trichomes, (g, h and i) multicellular gland head and ( $\mathrm{j}$ and $\mathrm{k}$ ) clavate gland head

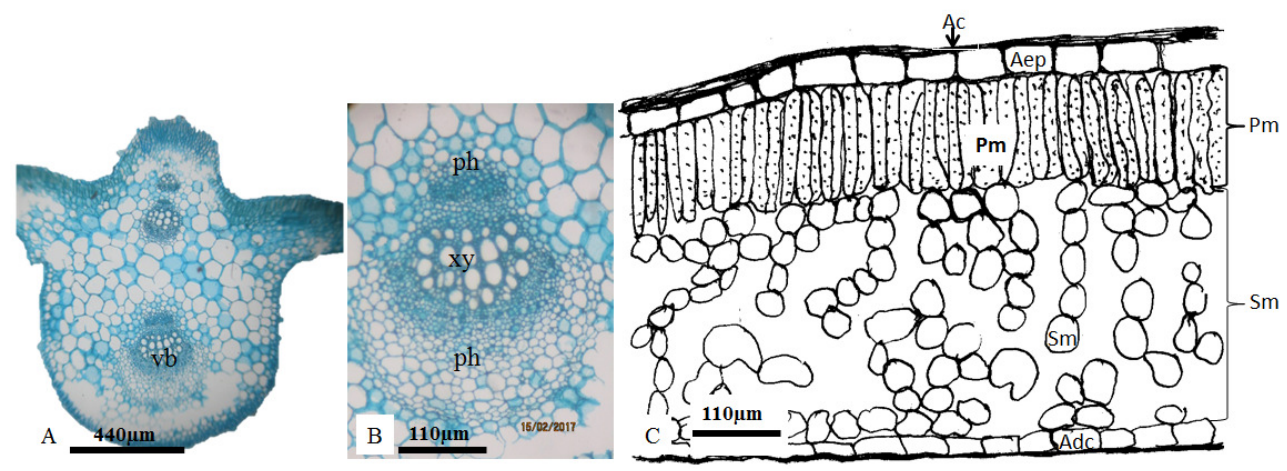

Fig. 5. Anatomy of B. hispida (A and B) midrib and (C) leaf lamina ( $\mathrm{vb}=$ vascular bundle, $\mathrm{xy}=\mathrm{xylem}, \mathrm{ph}=\mathrm{phloem}, \mathrm{Ac}=\mathrm{adaxial}$ cuticle, Aep = adaxial epidermis, $\mathrm{Pm}=$ palisade mesophyll, $\mathrm{Sm}=$ spongy mesophyll, $\mathrm{Adc}=$ abaxial epidermis $)$

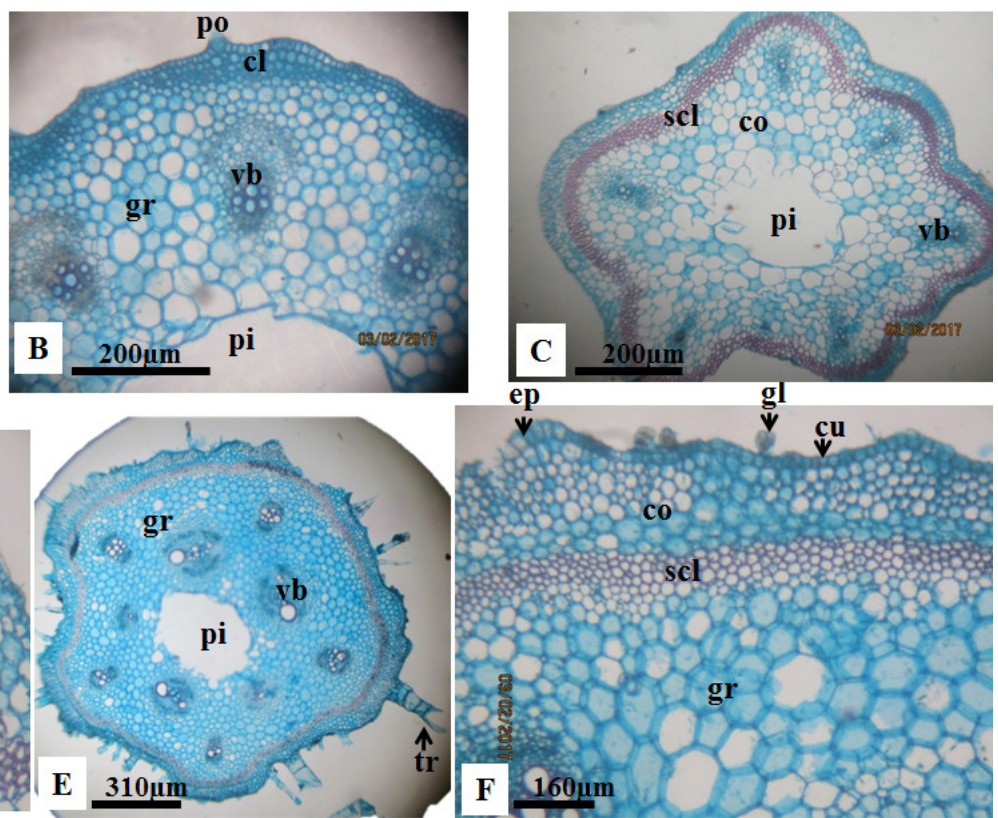

Fig. 6. Anatomy of stem of B. hispida (A and B), petiole ( $C$ and D) and Tendril (E and F) Abbreviations: vb = vascular bundle, pi $=$ pith, $\mathrm{cu}=$ cuticle, $\mathrm{ep}=$ epidermis, $\mathrm{po}=$ papillose, $\mathrm{co}=$ cortex, $\mathrm{gr}=$ ground tissue, $\mathrm{ph}=$ phloem, $\mathrm{xy}=\mathrm{xylem}, \mathrm{tr}=\operatorname{trichome}, \mathrm{scl}=$ sclerenchyma 

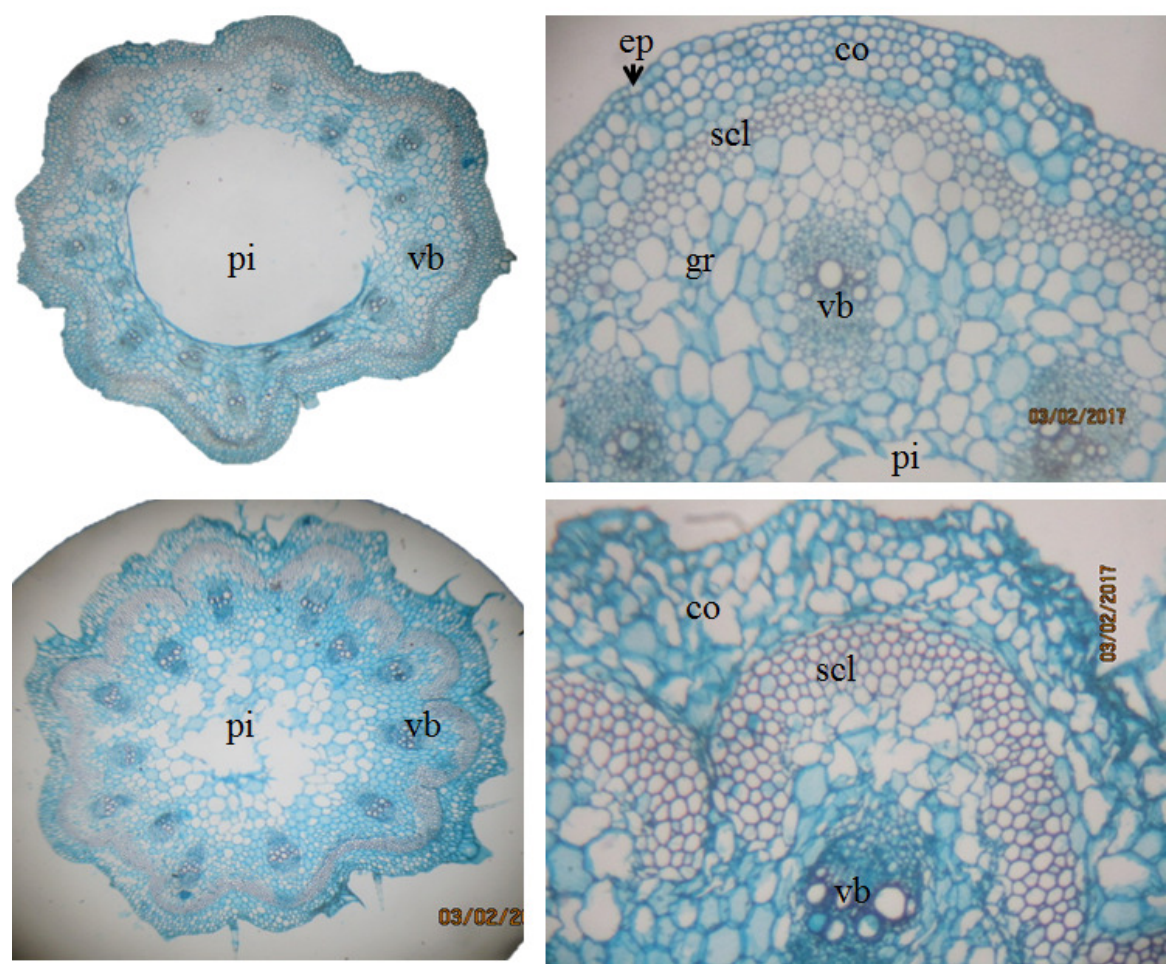

Fig. 7. Anatomy of flower stalks of B. hispida $(\mathrm{A}$ and $\mathrm{B})=$ male flower and $(\mathrm{C}$ and $\mathrm{D})=$ female flower $(\mathrm{pi}=\mathrm{pith}, \mathrm{vb}=\mathrm{vacular}$ bundle, $\mathrm{scl}=$ sclerenchymatous cells, $\mathrm{co}=$ cortex, $\mathrm{ep}=$ epidermal cell, $\mathrm{gr}=$ ground tissue)

Stem

The stem has hollow pith, 250 - $370 \mu$ m wide, cortex 83 - $96 \mu \mathrm{m}$ thick, sclerenchymatous cells $3-4 \mu \mathrm{m}$ thick with 10 vascular bundles in two concentric rings (Table 2, Figs. $6 \mathrm{E}$ and $\mathrm{F}$ ).

\section{Proximate and phytochemical composition}

The percentage crude protein, ash, carbohydrate, lipid, moisture, crude fibre, alkaloid, flavonoid, tannin and phytate concentrations are $0.37 \pm 0.03,0.52 \pm 0.08,3.23 \pm$
$0.11,0.42 \pm 0.07,94.20 \pm 0.10,1.25 \pm 0.06,4.20 \pm 0.10$, $1.13 \pm 0.15,0.09 \pm 0.01$ and $0.06 \pm 0.00$ and $0.49 \pm 0.02$, $0.21 \pm 0.01,3.36 \pm 0.05,0.60 \pm 0.10,95.40 \pm 0.53,0.32 \pm$ $0.02,4.35 \pm 0.05,0.95 \pm 0.05,0.07 \pm 0.02$ and $0.06 \pm 0.01$ for skin and pulp respectively (Table 3 ). Also, in the seeds the percentage concentrations of crude protein, ash, carbohydrate, lipid, moisture, crude fibre, tannin and phytate are $0.58 \pm 0.02,9.33 \pm 0.58,9.43 \pm 0.07,0.77 \pm$ $0.15,37.60 \pm 0.53,42.49 \pm 0.50,0.09 \pm 0.01$ and $0.06 \pm$ 0.00 (Table 3).

Table 3. Proximate and phytochemical composition of mature B. hispida $(\mathrm{g} / 100 \mathrm{~g})$

\begin{tabular}{|c|c|c|c|c|c|c|c|c|}
\hline \multirow{2}{*}{ Parameter } & \multicolumn{3}{|c|}{ Present work } & \multirow{2}{*}{$\begin{array}{l}\text { Wills et al. } \\
\text { (1984) }\end{array}$} & \multirow{2}{*}{$\begin{array}{c}\text { Morton, } \\
1971\end{array}$} & \multirow{2}{*}{$\begin{array}{c}\text { Tee et al. } \\
(1997)\end{array}$} & \multirow{2}{*}{$\begin{array}{c}\text { Mingyu et al. } \\
\text { (1995) }\end{array}$} & \multirow{2}{*}{ FAO, 1972} \\
\hline & Pulp & Skin & Seed & & & & & \\
\hline Moisture & $95.4 \pm 0.53$ & $94.20 \pm 0.10$ & $37.60 \pm 0.53$ & 96.80 & 96.2 & 94.5 & 96.7 & 96.20 \\
\hline Crude Protein & $0.49 \pm 0.02$ & $0.37 \pm 0.03$ & $0.58 \pm 0.02$ & 0.30 & 0.40 & 0.50 & 0.40 & 0.50 \\
\hline Carbohydrate & $3.36 \pm 0.05$ & $3.23 \pm 0.11$ & $9.43 \pm 0.07$ & 1.10 & 2.24 & 4.00 & 2.56 & 2.30 \\
\hline Crude fibre & $0.32 \pm 0.02$ & $0.42 \pm 0.07$ & $42.49 \pm 0.50$ & 1.50 & 0.68 & 0.5 . & 0.58 & 0.60 \\
\hline Lipid & $0.60 \pm 0.10$ & $1.25 \pm 0.06$ & $0.77 \pm 0.15$ & 0.00 & 0.03 & 0.20 & 0.00 & 0.10 \\
\hline Ash & $0.21 \pm 0.01$ & $0.52 \pm 0.08$ & $9.33 \pm 0.58$ & 0.30 & 0.45 & 0.30 & 0.27 & 0.30 \\
\hline Alkaloid & $4.35 \pm 0.05$ & $4.20 \pm 0.10$ & ND & NA & NA & NA & NA & NA \\
\hline Flavonoid & $0.95 \pm 0.05$ & $1.13 \pm 0.15$ & ND & NA & NA & NA & NA & NA \\
\hline Tannin & $0.07 \pm 0.02$ & $0.09 \pm 0.01$ & $0.09 \pm 0.01$ & NA & NA & NA & NA & NA \\
\hline Phytate & $0.06 \pm 0.01$ & $0.06 \pm 0.00$ & $0.06 \pm 0.00$ & NA & NA & NA & NA & NA \\
\hline Country & Nigeria & Nigeria & Nigeria & Australia & Florida & Malaysia & China & FAO \\
\hline
\end{tabular}


108

\section{Discussion}

Plant morphology is an important character used in plant classification. It is always used in combination with floral and anatomical features. In Cucurbitaceae, morphological characteristics have been employed in their classification (Hutchinson and Dalziel, 1954; Jeffrey, 1980, 2005; Okoli, 2013) while the application of anatomical features have been emphasized by Agbagwa and Ndukwu (2004), Ajuru and Okoli (2013), Ekeke et al. (2015), Agogbua et al. (2015a). In this study, morphology and anatomy of fruit, flower stalks, tendril, leaf and stem anatomy were investigated. Also, the epidermal characteristics of the leaf, petals male and female flowers were studied.

\section{Morphological attributes}

The morphological attributes of the B. hispida studied conform to the existing information on the species. For instance, Alejando (1998) reported average fruit size and weight of two accessions of B. hispida $55.5 \mathrm{~cm} \mathrm{x} 24.7 \mathrm{~cm}$ and $11.7 \mathrm{~kg}$ for green winter melon and $48.9 \mathrm{~cm} \mathrm{x} 22.1 \mathrm{~cm}$ and $6.1 \mathrm{~kg}$ for fuzzy white gourd. Also Sudhakar et al. (2008) recorded an average fruit weight of $3.06 \mathrm{~kg}$ to $13.67 \mathrm{~kg}$ and equatorial diameter of $52.99 \mathrm{~cm}$ to $80.11 \mathrm{~cm}$ in 34 accessions of $B$. hispida in India and in our study we recorded fruit size of $58.6-59.4 \mathrm{~cm}$ long, $14.0-15.5 \mathrm{~cm}$ wide and $8.5-9.0 \mathrm{~kg}$ (Table 3). These morphological characteristics are in line with the works of Jeffrey (1990), Alejandro (1998), Ahmed (2011) and suggest that this is a cultivar or an accession B. hispida (Alejandro, 1998; Sudhakar et al., 2008).

B. hispida is a monoecious climber with yellow flowers, hairy stem, petiole, leaf, petals and young fruits. The male flowers are solitary or in a slender-pedunculate racemes, fairly coaxillary with female flowers (Jeffery, 1980; Okoli, 1982; Ndukwu, 1988; Agogbua et al., 2015). However, majority of cucurbits such as Telfiaria esculenta, Citrullus lanatus Thunb and Cucurbita pepo L. are dioecious (Agbagwa and Ndukwu, 2004) while some other species are hermaphroditic (Hutchinson and Dalziel, 1954; Okoli, 1984; Ndukwu and Okoli, 1992). B. hispida exhibits similar characteristics with these species. This however supports the placement of these species in the Cucurbitaceae (Jeffrey, 1990).

\section{Epidermal characteristics}

The epidermal cells in the leaves and the petals are polygonal to irregular with anomcytic, tetracytic and anisocytic stomata. The anticlinal cell wall patterns are slightly straight, curved or undulating. Also, the leaf is amphistomatic. Okoli (1989), Ekeke et al. (2015), Agbagwa and Ndukwu (2004), Ajuru and Okoli (2013), Agogbua et al. (2015a) opined the fact that most members of this family are amphistomatic with anomocytic, tetracytic and isotricytic stomata types. Also Adebooye et al. (2012) reported more stomata on the abaxial than the adaxial surface of Trichosanthes cucumerina. In the same way, the stomatal indices in this study were more on the abaxial surfaces of the leaf and petals. This finding supports the existing data on the members of the family and thereby confirms the interspecific relationship between this species and other cucurbits.

\section{Trichome types}

Trichomes are of certain systematic significance and sometimes common types are even used for diagnostic purposes in association with other characters (Cutler 1984). The range of trichome variation in the Cucurbitaceae is enormous. The important aspects of variation of trichomes include the degree of modification of the adjacent epidermal cells and the scars left by lost trichomes, in addition to its distribution and anatomy. Generally, trichomes are categorised into glandular and the eglandular types. The significance of trichomes in relation to taxonomy has been shown in angiosperm families earlier by Gupta and Murty (1977) and Rao (1991).

Metcalfe and Chalk (1950) had made a survey of various types of trichomes in different genera of the Cucurbitaceae. According to them glandular hairs with multiseriate stalks is one of the major characteristics of this family, but simple unicellular or uniseriate types as well as wart-like or spiny trichomes are also present in the Cucurbitaceae. Both glandular and non-glandular trichomes were encountered during. Furthermore, other glandular trichomes identified among cucurbits include: club-shaped or globose with a multicellular head and a single stalk cell, club-shaped or elongate consisting of a multicellular head and two-celled stalk and multicellular clavate head with multicellular stalk. Also non-glandular trichomes such as uniseriate, 1-2 celled with a single basal cell, uniseriate and multicellular with a single basal cell, uniseriate and multicellular with biseriate basal cells and uniseriate and multicellular with a multicelled base trichomes are characteristics of Cucurbitaceae. Both glandular and eglandular trichomes were present in Benincasa hispida and noted that this wide range of trichome characters observed can be used for diagnostic purposes (Mohammad and Fahad, 2011). This is also consistent with the different types of glandular and eglandular trichomes that have been studied and described in cucurbits (Okoli, 1989; Agbagwa and Ndukwu, 2001; Kolb and Muller, 2004).

\section{Anatomy of stem, tendril, petiole and flower stalks}

The arrangement of the vascular bundles and hollow piths in the stem, tendril, petiole and the male flower stalk have been reported (Metcalfe and Chalk, 1950; Ekeke et al., 2015) and the concentric nature of the vascular bundles (Ekeke et al., 2017) have made similar observation in other members of cucurbits. The vascular bundles in cucurbits are bicollateral with varying sizes and mostly forming concentric rings in the stem, petiole and tendril (Metchalfe and Chalk, 1950; Agbagwa and Ndukwu, 2004; Ekeke et al., 2015; Agogbua et al., 2015a). Also, the tendril, female flower/fruit stalk and the stem showed remarkable layers of sclerenchymatous cells. The sclerenchymatous cells in the tendril, stem of $B$. hispida and male flower stalk are continuous while the ones in the female flower/fruit stalk are partly continuous or discontinuous. This is evident because they are used for anchoring the plant on other plants or to support the weight of the fruits (Ekeke et al., 2015). This report supports previous works by Metcalfe 
and Chalk (1950) and Ekeke et al. (2015) and a strong phylogenic bond between B. hispida and other members of Cucurbitaceae.

\section{Chemical composition and uses}

Regarding the chemical composition of B. hispida, Wills et al. (1984) noted that the pulp of B. hispida contains glucose and fructose and that their concentrations are 0.5 $0.9 \%$ and $0.5-0.8 \%$ respectively in matured fruits. Also, other authors from different parts of the world have analysed and reported the concentrations of moisture, carbohydrate, fibre, fat and ash in the pulp of mature fruit of B. hispida (Morton, 1971; FAO, 1972; Wills et al., 1984; Mingyu et al., 1995; Tee et al., 1997) in Australia, Florida, Malaysia and China (Table 3). Our result on the concentrations of these nutrients in the pulp of the specimen collected from the University of Port Harcourt Biodiversity Centre is similar to the works of these authors. However we further reported the concentration in the skin and seeds. The seeds had the highest concentrations of crude protein, ash, carbohydrate, lipid and fibre. This however suggests that the combination of the skin, pulp and seeds will be for medicinal and other purposes.

The fruits of Benincasa have been reported to contain different amino acids and several antioxidant properties (Mingyu et al., 1995; 2010; Yoshizumi et al., 1998) and the oil for B. hispida seeds as the best cucurbit seed oil from the hot and humid tropics (Martin, 1984; Lee et al., 2005; Sew et al., 2010). The presence of high crude protein and lipid in the seeds compared to other parts of the fruit studied in this work upholds the works of these previous authors and could account for the health benefits, therapeutic uses, pharmacological, medicinal and food properties of $B$. hispida (Uchikoba et al., 1998; Shih et al., 2001; Lee et al., 2005; Akinmoladun et al., 2007; Roy et al., 2008; Bhalodia et al., 2009; Qadrie et al., 2009; Monson, 2010; Girdhar et al., 2010).

\section{Conclusions}

The morphological, anatomical and phytochemical characteristics of $B$. hispisda from Nigerian are described for the first time. This species share the same ancestral characteristics in common with other members of Cucurbitaceae and supports the placement of this species in the family and the phytochemical constituents supports the medicinal, anti-compulsive effect, angiotensin-converting enzyme (ACE) inhibitor activity in vitro, Alzheimer disease treatment, anti-ulcer, anti-inflammatory, anti-obesity and anti-diarrheal agent of this species.

\section{Acknowledgements}

We wish to thank and appreciate the staff of the Department of Plant Science and Biotechnology, University of Port Harcourt for their assistance during the research work.

\section{References}

Adebooye OC, Hunsche M, Noga G, Lankes C (2012). Morphology and density of trichomes and stomata in Trichosanthes cucumerina (Cucurbitaceae) as affected by leaf age and salinity. Turkish Journal of Botany 36(4):328-335.

Agbagwa IO, Ndukwu BC (2001). Epidermal micro-morphology of Cucurbita L. species in Nigeria. Journal of Applied Sciences and Environmental Management 5(2):59-64.

Agbagwa IO, Ndukwu BC (2004). Cucurbita L. species in Nigeria underexploited food and vegetable crops. Niger Delta Biologia 4(2):11-15.

Agbagwa IO, Ndukwu BC, Mensah SI (2007). Floral biology, breeding system and pollination ecology of Cucurbita moschata (Duch. Ex Lam) Duch. Ex Poir. varieties (Cucurbitaceae) from parts of the Niger Delta, Nigeria. Turkish Journal of Botany 31(5):451-458.

Agogbua J, Ekeke C, Okoli BE (2015). Morpho-anatomical characters of Zehneria capillacea (Schumach) C. Jeffrey and Zehneria scabra (LF) Sond Cucurbitaceae. African Journal of Plant Science 9(12):457-465.

AgogbuaJU,EkekeC (2017).In vitro polyploidization of Zehneria capillacea (Shumach.) C. Jeffrey using nodal explants. Journal of Advances in Biology \& Biotechnology 13(2):1-13.

Agogbua UJ, Ekeke C, Okoli BE (2015). Effect of oryzalin treatments on polyploidy induction, phenotypic and quantitative traits of Zebneria capillacea (Shumach.) C. Jeffrey. International Journal of Tropical Agriculture 33(3):2067-2073

Aguoru CU, Okoli BE (2012). Comparative stem and petiole anatomy of West African species of Momordica L (Cucurbitaceae). African Journal of PlantScience 6(15):403-409.

AhmedF (2011). Encyclopedia of tropical plants. Published by Firefly Books Ltd.New York, USA pp 449.

Ajuru MG, Okoli BE (2013). The morphological characterization of the melon species in the family Cucurbitaceae Juss., and their utilization in Nigeria. International Journal of Modern Botany 3(2):15-19

Akinmoladun AC, Ibukun EO, Afor E, Akinrinlola BL, Onibon TR, ... Farombi EO (2007). Chemical constituents and antioxidant activity of Alstonia boonei. African Journal of Biotechnology 6(10):1197-1201.

Alejandro C (1998). Evaluation of two Benincasa bispida genotypes for fruit yield, vine growth, size and shape characteristics. Report - Cucurbit Genetics Cooperative 21:67-68.

Ammon HV, Thomas PJ, Phillips S (1974). Effect of oleic and recinoleic acid on net jejunal water and electrolyte movement. Journal of Clinical Investigation 53(2):374379.

AOAC (2000). Official Methods of Analysis, Association of Analytical Chemists, 7th ed. Association of Analytical Communities, Gaithersburg, MD.

AOAC (2006). Official Methods of Analysis, Association of Analytical Chemists, Washington DC (USA) 15th ed. Association of Analytical Communities, Gaithersburg, MD.

Bhalodia Y, Kanzariya N, Patel R, Patel N, Vaghasiya J, Jivani N (2009). Renoprotective activity of Benincasa cerifera fruit extract on ischemia/Reperfusion-Induced renal damage in rat. Iranian Journal of KidneyDiseases 3(2):80-85.

Cantuti CI, Shukitt-Hale B, Joseph JA (2000). Neurobehavioral aspects of 
110

antioxidants in aging. International Journal of Developmental Neuroscience 18(4-5):367-381.

Cheran N, Alok N, Vinod KD (2010). Effect of Benincasa hispida fruits on testosterone-induced prostatic hypertrophy in albino rats. Current Therapeutic Research 71(5):331-343.

Chike CPR, Dapper DV, Odee P (2006). Possible abortifacient effect of Zehneria cordifolia methanol extract on female Wistar rat. African Journal of AppliedZoology and Environmental Biology 8:140-145.

Cutler DF (1984). Systematic anatomy and embryology-recent developments. Current Concepts in Plant Taxonomy. Academic Press, London pp 108-125.

Cuzzocrea S, Riley DP, Caputi AP, Salvemini D (2001). Antioxidant therapy: A new pharmacological approach in shock, inflammation and ischemia/reperfusion injury. Pharmacological Reviews 53(1):135-159.

Du Q, Zhang Q, Ito Y (2005). Isolation and identification of phenolic compounds in the fruit of Benincasa hispidaby HSCCC. Journal of Liquid Chromatography \& Related Technologies 28(1):137-144.

Ekeke C, Agogbua J, Okoli BE (2015). Comparative anatomy of tendril and fruit stalk in Curcubitaceae Juss. from Nigeria. International Journal of Biological and Chemical Sciences 9(4):1875-1887.

Ekeke C, Agbagwa IO (2017). Survey of foliar trichomes in Combretum Loelf. (Combretaceae) in parts of West Africa. Journal of Plant Studies 6(2):9-17.

Ekeke C, Agogbua J, Okoli BE (2015). Comparative anatomy of tendril and fruit stalk in Curcubitaceae Juss. from Nigeria. International Journal of Biological and Chemical Sciences 9(4):1875-1887.

FAO (1972). Food composition table for use in East Asia. Food and Agriculture Organization and U.S. Department of Health, Education and Welfare: Rome. Retrieved 3 November 2017, from http://www.fao.org/docrep/003/X6878E/X6878E00htm.

FAO (2009). Food \& Agriculture Organization of the United Nations. Retrieved 2 November 2017, from. http: //faostatfao. org/ site/339/default.aspx.

Gaginella TS, Stewart JJ, Olson WA, Bass P (1975). Actions of ricinoleic acid and structurally related fatty acid on the gastro-intestinal tract II. Effects on water and electrolyte absorption in vitro. Journal of Pharmacology and Experimental Therapeutics 195(2):355-361.

Gill NS, Dhiman K, Bajwa J, Sharma P, Sood S (2010). Evaluation of free radical scavenging, anti-inflammatory and analgesic potential of Benincasa hispidaseed extract. International Journal of Pharmacology 6(5):652-657.

Sanchez-Alonso F, Lachica M (1987). Seasonal trends in the elemental content of plum leaves. Communication in Soil Science and Plant Analysis 18(1):31-44.

Girdhar S, Wanjari MM, Prajapati SK, Girdhar A (2010). Evaluation of anti-compulsive effect of methanolic extract of Benincasa hispidaCogn. fruit in mice. Acta Poloniae Pharmaceutica-Drug Research 67(4):417421.

Grover JK, Adiga G, Vats V, Rathi SS (2001). Extracts of Benincasa bispidaprevent development of experimental ulcers. Journal of Ethnopharmacology 78(2-3):159-164.

Han JS, Oh DG, Mok IG, Park HG, Kim CK (2004). Efficient plant regeneration from cotyledon explants of bottle gourd (Lagenaria siceraria Standl). Plant Cell Reports 23(5):291-296.

Harborne JB (1984). Phytochemical compounds. In Phytochemical methods. Springer, Dordrecht, pp 37-99.

Huang HY, Huang JJ, Tso TK, Tsai YC, Chang CK (2004). Antioxidant and angiotension-converting enzyme inhibition capacities of various parts of Benincasa hispida (waxgourd). Nahrung 48(3):230-233.

Hutchinson J, Dalziel JM (1954). Flora of West Tropical Africa. Crown Agents, London UK.

Jeffrey CA (1980). A review of the Cucurbitaceae. Botanical Journal of the Linnaean Society 81:233-247.

Jeffrey CA (1990). An outline classification of the Cucurbitaceae. In: Bates DM, Robinson RW, Jeffrey C (eds.). Biology and utilization of the Cucurbitaceae. Cornell University Press Ithaca, NY,pp 449-463.

Jeffrey CA (2005). A new system ofCucurbitaceae. BotanicheskiiZhurnal 90:3332-3335.

Kolb D, Muller M (2004). Light, conventional and environmental scanning electron microscopy of the trichomes of Cucurbita pepo subsp. pepo var. styriaca and histochemistry of glandular secretory products. Annals of Botany 94(4):515-526.

Kumar A, Vimalavathini R (2004). Possible anorectic effect of methanol extract of Benincasa hispida (Thunb.) Cong, fruit. Indian Journal of Pharmacology 36(6):348-350.

Lee KH, Choi HR, Kim CH (2005). Anti-angiogenic effect of the seed extract of Benincasa hispidaCogniaux. Journal of Ethnopharmacology 97(3):509-513.

Maciuk A, Bouchet MJ, Mazars G, Um BH, Anton R (2002). Nootropic (medhya) plants from ayurvedic pharmacopoeia. 4th European Congress on Ethnopharmocology proceeding "From the Sources of Knowledge to the Medicines of the Future"11-13 May 2000, pp $402-$ 411.

Malvey P (2004). Structure, nomenclature and classification of stomata. Acta BotanicaSinica 44(2):242-252.

Martin FW (1984). Cucurbit seed as possible oil and protein sources. Echo Technical Note. Retrieved 31 October 2016, from http://www.echotech.org/network/modules.php?name =News \& file $=$ article $\&$ sid $=592$.

Mathad VSB, Chandanam S, Setty SRT, Ramaiyan D, Veeranna B, Lakshminarayanasettry ABV (2005). Antidiarrheal evaluation of Benincasa bispida (Thunb.) Cogn. fruit extract. Iranian Journal of Pharmacology and Therapeutics 4(1):24-27.

Metcalfe CR, Chalk L (1950). Anatomy of the Dicotyledons. At The Clarendon Press: Oxford,London, pp 684691.

Metcalfe CR, Chalk L (1979). Anatomy of the Dicotyledons. 2nd Edn., At The Clarendon Press, Oxford,London, pp 276.

Mini-Raj N, Prasanna KP, Peter KV (1993). Ash gourd Benincase hispida (Thunb.) Cogn. In: Genetic Improvement of Vegetable Crops. Eds. KalloG, Bergh BO, pp 235-238.

Mohammad AA, Fahad MAA (2011). Taxonomic significance of trichomes micromorphology in cucurbits, Saudi Journal of Biological Sciences 18(1):87-92.

Monson K (2010). Benefits of GABA. Retrieved 12 August 2017, from 
http://weight-loss.emedtv.com/gaba/benefits-of-gabahtml

Morton JF (1971). The wax gourd, a year-round Florida vegetable with unusual keeping quality. Proceeding of the Florida State Horticultural Society 84:104-109.

Nadhiya K, Vijayalakshmi K, Gaddam ARG (2016). Antiobesity effect of Benincasa hispidaFruit extract in high fat diet fed Wistar albino rats. International Journal of Pharmaceutical and Clinical Research 8(12):1590-1599

Ndukwu BC (1988). Morphological, anatomical and cytological studies on some lesser known Nigerian Cucurbits. M.Sc. Thesis, University of Port Harcourt. Nigeria.

Ndukwu BC, Okoli BE (1992). Studies on Nigerian Curcurbita moschata. Nigerian Journal of Botany 5:18-26.

Nurul AMZ, Farooq A, Azizah AH, Nazamid S (2011). Kundur [Benincasa hispida (Thunb.) Cogn.]: A potential source for valuable nutrients and functional foods. Food Research International 44(7):2368-2376.

Okoli BE (1984). Wild and cultivated cucurbits in Nigeria. Economic Botany 38(3):350-357.

Okoli BE (1987). Anatomical studies in the leaf and probract of Telferia Hooker (Curcurbitaceae). Feddes Repertorium 98:231-236

Okoli BE (1989). SEM study of surface characteristics of the vegetative and reproductive organs of Telferia (Cucurbitaceae). Phytomorphology 39:103-108.

Okoli BE (2013). Fluted pumpkin, Telfairia- the under-exploited golden treasure. University of Port Harcourt Press, Nigeria.

Omara-Achong TE, Edwin-Wosu NL, Edu EA, Nkang AE (2012). Survey of indigenous vegetables species in parts of Ogoja and Calabar, Cross River State, Nigeria. European Journal of Experimental Biology 2(4):1289-1301.

Qadrie ZL, Hawisa NT, Khan MWA, Samuel M, Anandan R (2009). Antinociceptive and anti-pyretic activity of Benincasa hispida (Thunb.) Cogn. in Wistar albino rats. Pakistan Journal of Pharmaceutical Sciences 22(3):287-290.

Rachchh MA, Jain SM (2009). Gastroprotective effect of Benincasa hispidafruit extract. Indian Journal of Pharmacology 40(6):271-275.

Rao TA (1991). Compendium of foliar sclereids in angiosperms. New Delhi: WileyEastern.

Robinson RW, Decker-Walters DS (1997). Cucurbits. New York: CAB International. Simonds NW 1976. Evaluation of Crop Plants, 1st edn. New York: Longman.

Roy C, Ghosh TK, Guha D (2008). Dose dependent activity of Benincasa bispidaon colchicines induced experimental rat model of Alzheimer's disease. International Journal of Pharmacology 4(4):237-244.

Rubatzky VE, Yamaguchi M (1997). Chinese winter melon / wax gourd Benincase hispida (Thunb.) Cogn. In: World Vegetables: principles, production, and nutritive values. Chapman Hall, ITP pp 625-627.
Schaefer H, Renner SS (2011). Phylogenetic relationships in the order Cucurbitales and a new classification of the gourd family (Cucurbitaceae). Taxon 60(1):122-138.

Sew CC, Zaini NAM, Anwar F, Hamid AA, Saari N (2010). Nutritional composition and oil fatty acids of Kundur [Benincasa hispida (Thunb.) Cogn.] seed. Pakistan Journal of Botany 42(5):3247-3255.

Shakti PP, Iftekhar A, Anisuzzaman M, Kanak KS, Shamina AS, Mohammad FA (2007). Indirect organogenesis in summer squash (Cucurbita pepo L.). Turkish Journal of Agriculture and Forestry 31(1):63-70.

Sheikh SA, Nowreen J, Md. Ahashan H, Mohammad NI (2012). Cytogenetical and molecular characterization of five commercial varieties in Trichosanthes anguina L. Cytologia 77(2):155-162

Shetty BV, Arjuman A, Jorapur A, Samanth R, Yadav SK, ... Valliammai N (2008). Effect of extract of Benincasa hispidaon oxidative stress in rats with Indomethacin induced gastric ulcers. Indian Journal of Physiology and Pharmacology 52(2):178-182.

Shih CT, Wu J, Jia S, Khan AA, Ting KH, Shih DS (2001). Purification of an osmotin-like protein from the seeds of Benincasa bispida and cloning of the gene encoding this protein. Plant Science 160(5):817-826.

Stephens JM (1988). Manual of minor vegetables. Florida Cooperative Extension Service. Bulletin SP-40,pp 54.

Sudhakar P, Sanjeev K, Upama M, Ashutosh R, Major S, Mathura R (2008). Genetic diversity in Indian ash gourd (Benincasa hispida) accessions as revealed by quantitative traits and RAPD markers. Scientia Horticulturae 118(1):80-86

Tee ES, Noor MI, Azudin MN, Idris K (1997). Nutrient composition of Malaysian foods (Komposisi zat dalam makanan Malaysia). Malaysian Food Composition Database Programme (pp 46-47). (4th ed.). Kuala Lumpur: Institute for Medical Research.

Uchikoba T, Yonezawa H, Kaneda M (1998). Cucumisin like protease from the sarcocarp of Benincasa bispidavar. Ryukyu. Phytochemistry 49(8):2215-2219.

Whitaker TW, Davis GN (1962). Cucurbits - botany, cultivation, utilization. Interscience Publishers, Inc, New York pp 249.

Wills RBH, Wang A, Scriven FM, Green-Field H (1984). Nutrient composition of Chinese vegetables. Journal of Agriculture and Food Chemistry32(2):413-416.

Yaniv Z, ShabelskyE, Schafferman D (1999). Colocynth: potential arid land oilseed from an ancient cucurbit. In: Prespective on new crops and new uses. ASHS Press, Alexandria, Virginia, pp 257-261.

YoshizumiS, Murakami T, Kadoya M, Matsuda H, YamaharaJ, Yoshikawa M (1998). Medicinal foodstuffs. XI. Histamine release inhibitors from wax gourd, the fruits of Benincasa bispida Cogn. Yakugaku Zasshi: Journalof the Pharmaceutical Society ofJapan 118(5):188-192.

Zhang SY (1996). Cosmetic and medicinal effects of the fruit of Benincasa hispida. Zhongguo Mingiian Liofa 4:44-49. 